\title{
Risk factors of rotavirus diarrhea in hospitalized children in Sanglah Hospital, Denpasar: a prospective cohort study
}

Hendra Salim ${ }^{1 *}$, I Putu Gede Karyana ${ }^{1 \dagger}$, I Gusti Ngurah Sanjaya-Putra ${ }^{1 \dagger}$, Soetjiningsih Budiarsa ${ }^{2+}$ and Yati Soenarto ${ }^{3+}$

\begin{abstract}
Background: Diarrhea is a major public health concern throughout the world because the prevalence of morbidity of diarrhea has not changed significantly in the past decade. It remains the third leading cause of death among children less than 5 years of age. Recent surveillance studies have shown that rotavirus is a significant cause of pediatric hospitalization and death due to diarrhea. Indonesia has limited data on risk factors, disease burden, and deaths in children due to rotavirus diarrhea. The objective of this study was to examine the above mentioned factors related to rotavirus diarrhea in hospitalized children in Sanglah Hospital, Denpasar.
\end{abstract}

Methods: A prospective cohort study was conducted at Sanglah Hospital Denpasar from April 2009 to December 2011. The present study was part of a nationwide study on Extension for Hospital-based Surveillance and Strain Characterization of Rotavirus Diarrhea Indonesia involving four hospitals throughout Indonesia as a part of the Asian Rotavirus Surveillance Network. We studied children aged $<5$ years who were hospitalized with acute diarrhea, and analyzed their stool samples using an immunoassay that detects the rotavirus antigen.

Results: A total of 656 patients met the inclusion criteria for this study. Of 5805 patients under the age of 5 who were hospitalized between April 2009 and December 2011, the prevalence of diarrhea among hospitalized pediatric patients was $11.3 \%$ and the prevalence of rotavirus diarrhea was $49.8 \%$. The male to female ratio of those affected by rotavirus was 1.6:1. The occurrence of vomiting was significantly higher in rotavirus diarrhea than in non-rotavirus diarrhea (RR, 1.4; 95\% Cl, 1.08 to 1.70; $p=0.004)$.

Conclusions: Diarrhea remains an important cause of hospitalization in children, and rotavirus was the most important etiology. We found that boys had a greatest risk of rotavirus infection than girls. Good nutritional status and breastfeeding provided the same protection against rotavirus and non-rotavirus diarrhea.

Keywords: Acute diarrhea, Rotavirus, Children

\section{Background}

Rotavirus is recognized as a major cause of non-bacterial gastroenteritis (infection of the stomach and intestinal tract leading to diarrhea and vomiting) especially in infants and young children worldwide [1,2]. Rotavirus gastroenteritis is endemic worldwide. The infection is associated with high rate of morbidity throughout the world and a high rate of mortality in developing countries. It account for more than 800,000 child deaths per

\footnotetext{
* Correspondence: misionarispelayanan@yahoo.com

${ }^{\dagger}$ Equal contributors

'Division of Gastroenterology and Hepatology, Department of Child Health, Medical School, Udayana University/Sanglah Hospital, Denpasar, Indonesia
} Full list of author information is available at the end of the article year due to poor nutrition and health care in developing countries [3].

Diarrhea has been estimated to cause 1.5 million deaths and $21 \%$ of deaths worldwide in children under the age of 5 [4]. In India, most cases of diarrhea (98\%) occurred during the first 2 years of life, peaking at $9-11$ months [2]. Based on a literature review of studies published between 1986 and 1999 on childhood deaths caused by diarrhea and hospitalizations due to rotavirus, it was estimated that 440,000 annual deaths in children aged $<5$ years occur because of rotavirus infection [1]. An estimated 527,000 children aged $<5$ years died from rotavirus infection in 2004 with $>85 \%$ of these deaths in 
South-East Asia and sub-Saharan Africa [5]. Of 8929 Indonesian children in Purworejo district and Yogyakarta city hospitalized between August 2001 and April 2004, $16 \%$ presented with acute gastroenteritis, and $53 \%$ of the 1321 tested stool samples were positive for rotavirus [6].

This study involved children aged $<5$ years who were admitted with diarrhea in Sanglah Hospital, and the aims were to determine the prevalence of acute diarrhea and the rotavirus disease, and to determine the risk factors for rotavirus diarrhea.

\section{Methods}

We conducted a prospective cohort study from April 2009 to December 2011 of hospitalized children with acute diarrhea. The study was a part of the study on Extension for Hospital-based Surveillance and Strain Characterization of Rotavirus Diarrhea Indonesia involving four hospitals throughout Indonesia as part of the Asian Rotavirus Surveillance Network.

For the sample size, we used a risk ratio of $1.1, \alpha=0.05$, $\beta=0.2$, and the proportion of individuals exposed to the outcome was $91 \%$. The minimal sample size required was 494 patients. This study was approved by the Medical and Health Research Ethics Committee of the Faculty of Medicine, Gadjah Mada University, and parents' written consent was obtained for participation in this study.

The study group included patients less than 5 years of age hospitalized with acute diarrhea. Patients admitted with diarrhea lasting more than 7 days and those with chronic diarrhea due to malabsorption and structural malformations were excluded from the study. We excluded diarrhea lasting more than 7 days because prolonged or persistent diarrhea are not usually caused by rotavirus.

The parents were questioned about the chief complaints and the degree of dehydration was examined. Parents were given a sterile screw-capped plastic container for collection of stool specimen within 24 hours after admission. A standardized clinical form was completed to obtain detailed information on the date of admission, age and sex of the patient, nutritional status, previous treatment, hydration status, symptoms, and final diagnosis.

For this study, we defined acute diarrhea as $>3$ loose stools within a 24-hour period [7] with a duration $<7$ days, and prolonged diarrhea was defined as an illness lasting between 7 and 14 days [8-10]. Vomiting was defined as the forceful expulsion of gastric contents at least once in a 24-hour period. Fever was defined by the presence of an axillary temperature greater than or equal to $38^{\circ} \mathrm{C}$. If present, dehydration was graded as mild (dry mucus membranes, decreased tears and urine output), moderate (decreased skin turgor), or severe (excessively decreased skin turgor, tachycardia, low blood pressure, anuria, absence of tears) [11]. Breastfeeding was defined as provision of breast milk, either directly from the breast or expressed, and may constitute any portion of the infant's diet.

A sufficient amount of whole stool specimen (5-10 ml) was collected for all admitted cases in a sterile screwcapped plastic container. Stool samples were divided in two sets: one was used for routine stool examination and the other was transported in refrigerated boxes to the Microbiology Laboratory at Gadjah Mada University, Faculty of Medicine, in Yogyakarta. It was stored at 4$8^{\circ} \mathrm{C}$ until laboratory testing for rotavirus. In the laboratory, the sample was aliquoted and stored at $-70^{\circ} \mathrm{C}$. Rotavirus was detected using an enzyme immunoassay for rotavirus (Dakopatts ${ }^{\circ}$, Dako Diagnostics Ltd., United Kingdom) in accordance with the manufacturer's instructions.

Data were entered by a single investigator into the database that consists of information about clinical variables and rotavirus test results. Statistical analysis was performed using the SPSS 16.0 program. The final data were analyzed using the chi-square test and risk ratio to determine the significance of relevant parameters. The chi-square test was used with $95 \%$ confidence interval.

\section{Results}

Patient demographics, clinical characteristics and laboratory findings are listed in Tables 1 and 2. Of the 656 cases, $577(88.0 \%)$ had mild to moderate dehydration and 24 (3.7\%) had severe dehydration. Two patients died and the case fatality rate was $0.3 \%$. Of the 5805 patients below the age of 5 years who were admitted between April 2009 and December 2011, the prevalence of diarrhea was $11.3 \%$ and the prevalence of rotavirus infection in these hospitalized patients was $49.8 \%$.

This study found an association between the occurrence of rotavirus and chief complain on admission, degree of dehydration, presence of vomiting (Table 2), and

\section{Table 1 Patient characteristics}

\begin{tabular}{lc}
\hline Characteristics & Total $(\mathbf{n}=\mathbf{6 5 6})$ \\
\hline Sex, male, $\mathrm{n}(\%)$ & $400(61.0)$ \\
Age, median (IQR) month & $12.8(7.5-20.4)$ \\
Weight, median (IQR) kg & $8.5(7-10)$ \\
Height, median (IQR) cm & $75(66-84)$ \\
Degree of dehydration, $\mathrm{n}(\%)$ & \\
$\quad$ No dehydration & $55(8.4)$ \\
$\quad$ Mild-moderate & $577(88.0)$ \\
$\quad$ Severe & $24(3.7)$ \\
Length of stay, median (IQR) day & $3(3-4)$ \\
Rotavirus positive, $\mathrm{n}(\%)$ & $327(49.8)$ \\
\hline
\end{tabular}

$\mathrm{IQR}=$ Interquartile range. 
Table 2 Clinical manifestations in children with rotavirus and non-rotavirus diarrhea

\begin{tabular}{|c|c|c|c|}
\hline Variables & Rotavirus positive $(n=327)$ & Rotavirus negative $(n=329)$ & RR $(95 \% \mathrm{Cl}), \mathrm{p}$ value \\
\hline \multicolumn{4}{|l|}{ Chief complain, n (\%) } \\
\hline - Diarrhea & $302(92.4)$ & $276(83.9)$ & 1.0 (Referent group) \\
\hline - Vomiting & $9(2.8)$ & $21(6.4)$ & 1.7 (1.00 to 3.02$), 0.017$ \\
\hline - Others & $16(4.9)$ & $32(9.7)$ & 1.6 (1.04 to 2.36$), 0.012$ \\
\hline \multicolumn{4}{|c|}{ General condition at admission, n (\%) } \\
\hline - Well & $155(47.4)$ & $150(45.6)$ & 1.0 (Referent group) \\
\hline - Irritable & $155(47.4)$ & $155(47.1)$ & 1.0 (0.87 to 1.19$), 0.84$ \\
\hline - Lethargy & $17(5.2)$ & $24(7.3)$ & 1.2 (0.84 to 1.79$), 0.26$ \\
\hline \multicolumn{4}{|c|}{ Degree of dehydration, n (\%) } \\
\hline - No dehydration & $17(5.2)$ & $38(11.6)$ & 1.0 (Referent group) \\
\hline - Mild-moderate & $299(91.4)$ & $278(84.5)$ & 0.6 (0.40 to 0.89$), 0.03$ \\
\hline - Severe & $11(3.4)$ & $13(4.0)$ & 0.7 (0.38 to 1.21$), 0.20$ \\
\hline Vomiting, n (\%) & $275(84.1)$ & $247(75.1)$ & 1.4 (1.08 to 1.70$), 0.004$ \\
\hline Seizure, n (\%) & $23(7.0)$ & $30(9.1)$ & 0.9 (0.63 to 1.18$), 0.33$ \\
\hline Fever, n (\%) & $203(62.1)$ & $195(59.3)$ & 1.1 (0.90 to 1.24$), 0.46$ \\
\hline Bloody diarrhea, n (\%) & $1(0.3)$ & $7(2.1)$ & 4.0 (0.64 to 25.22 ), $0.07^{*}$ \\
\hline \multicolumn{4}{|l|}{ Outcome, n (\%) } \\
\hline - Recovered & 319 (97.6) & $319(97.0)$ & 1.0 (Referent group) \\
\hline - Referral/Death & $8(2.4)$ & $10(3.0)$ & 1.1 (0.67 to 1.90$), 0.64$ \\
\hline
\end{tabular}

*Fisher's exact test.

sex (Table 3), but no association was seen between rotavirus infection and nutritional status, breastfeeding, symptoms of seizure, fever, and hand washing behavior.

A multivariate analysis showed that nutritional status, capability to eat by him/herself, fed by parent, breastfeeding, and bottle-feeding were protective factors for rotavirus diarrhea, but these results were not statistically significant (Table 4). This study showed that rotavirus diarrhea was more frequent in boys than girls (adjusted $\mathrm{RR}, 1.4 ; 95 \% \mathrm{CI}, 1.04$ to $1.97 ; \mathrm{p}=0.03$ ).

Table 3 Risk factors for children with rotavirus and non-rotavirus diarrhea

\begin{tabular}{|c|c|c|c|}
\hline Variables & Rotavirus positive $(n=327)$ & Rotavirus negative $(n=329)$ & RR $(95 \% \mathrm{Cl})$, p value \\
\hline Sex, Male, n (\%) & $214(65.4)$ & $186(56.5)$ & 1.2 (1.03 to 1.43$), 0.019$ \\
\hline \multicolumn{4}{|l|}{ Age, n (\%) month } \\
\hline $0-<3$ & $19(5.8)$ & $22(6.2)$ & 1.0 (Referent group) \\
\hline $3-<6$ & $34(10.4)$ & 35 (10.6) & 0.9 (0.63 to 1.41$), 0.77$ \\
\hline $6-<12$ & $93(28.4)$ & $89(27.1)$ & 0.9 (0.63 to 1.30$), 0.58$ \\
\hline $12-<24$ & $129(39.4)$ & $109(33.1)$ & 0.9 (0.60 to 1.21$), 0.35$ \\
\hline $24-<36$ & $33(10.1)$ & $45(13.7)$ & 1.1 (0.72 to 1.67$), 0.67$ \\
\hline $36-<48$ & $12(3.7)$ & $15(4.6)$ & 1.0 (0.61 to 1.78$), 0.88$ \\
\hline $48-<60$ & $7(2.1)$ & $14(4.3)$ & 1.4 (0.70 to 2.77$), 0.33$ \\
\hline \multicolumn{4}{|l|}{ Nutritional status, n (\%) } \\
\hline Well-nourish & $231(70.6)$ & $221(67.2)$ & 1.0 (Referent group) \\
\hline Malnourish & $96(29.4)$ & $108(32.8)$ & 1.1 (0.92 to 1.29$), 0.34$ \\
\hline Family member with diarrhea, $\mathrm{n}(\%)$ & $37(11.3)$ & $26(7.9)$ & 1.2 (0.96 to 1.50$), 0.14$ \\
\hline Eat by him/herself, n (\%) & $73(22.3)$ & $83(25.2)$ & 0.9 (0.76 to 1.11$), 0.38$ \\
\hline Fed by parent, n (\%) & $101(30.9)$ & $111(33.7)$ & 0.9 (0.79 to 1.11$), 0.43$ \\
\hline Breastfeeding, n (\%) & $125(38.3)$ & $122(37.1)$ & 1.0 (0.88 to 1.20 ), 0.76 \\
\hline Bottle-feeding, n (\%) & $245(74.9)$ & $245(74.5)$ & 1.0 (0.85 to 1.21$), 0.89$ \\
\hline
\end{tabular}


Table 4 Multivariate analysis of risk factors for rotavirus diarrhea

\begin{tabular}{lcc}
\hline Variables & $\begin{array}{c}\text { Regression } \\
\text { coefficient }\end{array}$ & $\begin{array}{c}\text { Adjusted RR (95\% Cl), } \\
\text { p value }\end{array}$ \\
\hline Sex & 0.361 & $1.4(1.04$ to 1.97$), 0.03$ \\
Nutritional status & -0.117 & $0.9(0.64$ to 1.24$), 0.50$ \\
Family member with diarrhea & 0.404 & $1.5(0.88$ to 2.55$), 0.14$ \\
Eat by him/herself & -0.100 & $0.9(0.60$ to 1.36$), 0.63$ \\
Fed by parent & -0.094 & $0.9(0.65$ to 1.28$), 0.59$ \\
Breastfeeding & -0.052 & $0.9(0.68$ to 1.33$), 0.76$ \\
Bottle-feeding & -0.028 & $0.9(0.66$ to 1.44$), 0.89$ \\
\hline
\end{tabular}

\section{Discussion}

Diarrheal disease remains a significant health problem in many parts of the world [12]. Rotavirus is an important cause of diarrhea and contributes significantly to diarrhea in both developing and developed countries [13]. In Nepal, rotavirus accounts for up to $38 \%$ of diarrhea in children less than 5 years old [12]. In the 43 countries participating in the global surveillance network for rotavirus in 2009, 36\% of hospitalizations for diarrhea among children aged $<5$ years were caused by rotavirus infection. Surveillance of the period between 2001 and 2008 revealed a detection rate of $40 \%$ in 35 countries with the virus distributed in similar regions [14]. The present study revealed that rotaviruses are important etiologic agents of acute diarrhea, accounting for $49.8 \%$ of all cases of acute gastroenteritis.

Rotavirus was detected in a higher proportion of males than females (RR, 1.2; 95\% CI, 1.03 to $1.43 ; \mathrm{p}=0.019$ ), indicating that males had a higher rotavirus stool excretion rate than females [3]. The male to female ratio of rotavirus infection was 1.6:1. This is in agreement with the finding that boys are twice more susceptible to rotavirus infection than girls and are more likely to be hospitalized [15]. Junaid et al. reported that the ratio was 1.8:1 in Nigeria, while Samir et al. and Puri et al. reported ratios of 1.5:1 and 1:2.4 for Bahrain and India, respectively [3]. According to the WHO scientific group [13,16], the number of affected males was up to $20 \%$ higher than the number of females in some studies, but it is not known whether this is due to a greater susceptibility to rotavirus exposure in boys or a greater likelihood of parents of affected boys seeking medical care.

According to the WHO scientific working group [13,16], most cases of rotavirus infections occur in children between 6 and 24 months with a peak incidence at 9 to 12 months. A surveillance conducted in 6 hospitals in 6 provinces of Indonesia found that children aged $<3$ months are less likely to have rotavirus diarrhea. Our findings confirmed that children aged $<3$ months are less susceptible to rotavirus, and children between 6 and 24 month are highly susceptible to rotavirus diarrhea.

Rotavirus is spread by direct person-to-person contact. Effective hand washing and disposal or disinfection of contaminated items are important measures in the prevention of rotavirus infection. Breastfeeding reduces gastrointestinal infections as breast milk contains lactadherin that is protective against symptomatic rotavirus infection. Lactadherin, secretory IgA, T-and B-lymphocytes, bactericidal lactoferrin, oligosaccharides and human milk glycans in breast milk protect the intestinal epithelium against pathogens. Human milk also contains antirotavirus antibodies that seem to play a smaller role against pathogens. Current WHO guidelines on the management of diarrhea recommend continued breastfeeding during a diarrhea episode [4].

One study asserted that transplacentally acquired immunoglobulin $\mathrm{G}$ antibodies and immunoglobulin $\mathrm{A}$ in breastmilk protect children aged $<3$ months against rotavirus infection. Human breast milk contains other components, including milk mucin, which have been shown to inhibit rotavirus replication and infection by binding to the virus $[17,18]$.

A prospective study by Naficy et al. found a lower incidence of rotavirus diarrhea in infants that received breast milk [19]. Duffy et al. [20] followed a cohort of 197 infants and found no difference in rotavirus infection rates between the breast-fed and bottle-fed infants. Furthermore, a study by Wobudeya et al. [4] failed to show that breastfeeding was protective against rotavirus diarrhea in infants. Our study found no difference in rotavirus infection rates between bottle-fed and non-bottle-fed infants.

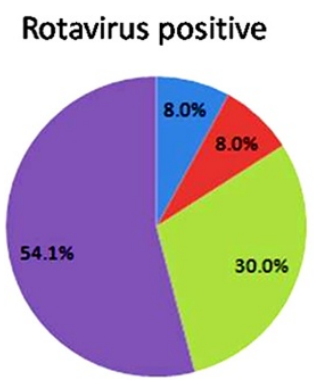

Rotavirus negative
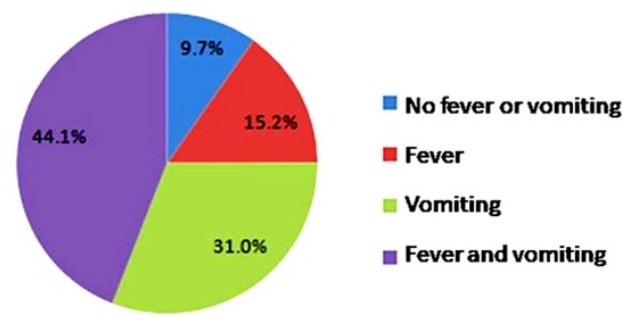

Figure 1 Comparison of symptoms of fever and vomiting between rotavirus and non-rotavirus diarrhea. 

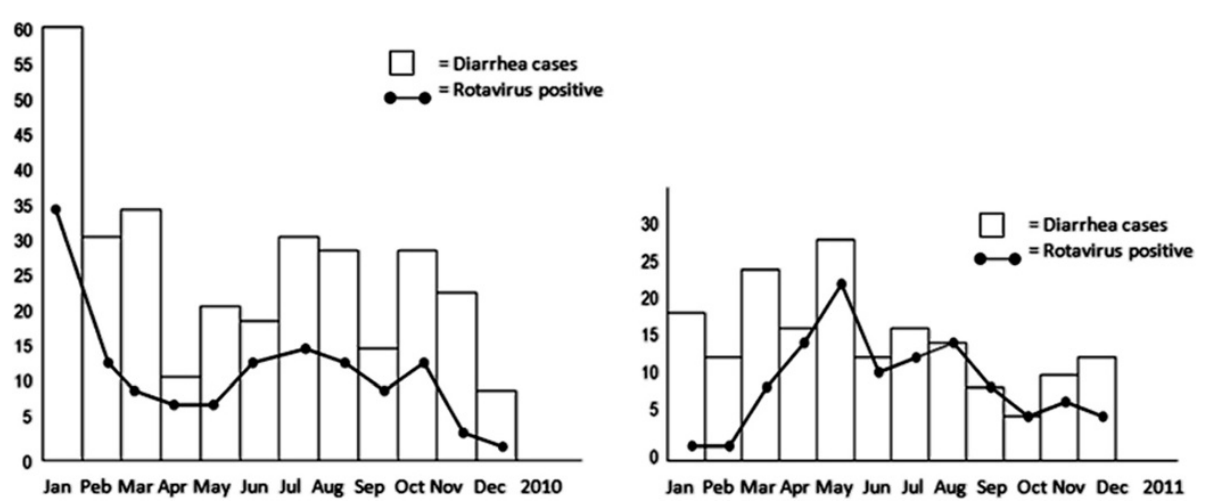

Figure 2 Seasonal variation in rotavirus positivity.

The close relationship between age, breastfeeding and rotavirus diarrhea could probably explain the observations in these reports. The peak age for rotavirus diarrhea is 6-11 months while the rates of breastfeeding begin to decline after 6 months. The protective effects of breastfeeding seem to wane with age [4]. This might explain why studies that focused on infants 6 months or younger tended to show the protective effect of breastfeeding.

Vomiting appears to be more common in children with rotavirus diarrhea than those with non-rotavirus diarrhea [3]. The present study found that $83.3 \%$ of hospitalized children with rotavirus diarrhea presented with vomiting ( $R R, 1.4 ; 95 \% \mathrm{CI}, 1.08$ to $1.70, \mathrm{p}=0.004$ ). The occurrence of the symptoms of diarrhea, fever and vomiting was significantly different between children with rotavirus diarrhea and those with non-rotavirus diarrhea [3]. The present study found that $54.1 \%$ of cases of rotavirus diarrhea presented with both fever and vomiting (Figure 1). These symptoms could increase the risk of dehydration and hospitalization. Although there appears to be an increasing trend in admitting young children with diarrhea, this appears to be associated with a low mortality, possibly because of better hospital clinical management [6].

Rotavirus diarrhea occurs year round but there is an apparent increase in the prevalence of rotavirus infection in the cool, dry season. A study in Indonesia showed a clear seasonal trend of rotavirus infection in the hot and dry seasons with low humidity $[6,17]$. Another study in India found that $64.8 \%$ of rotavirus cases occurred in the cooler months i.e., from November to January. The present study found no consistent pattern in the number of rotavirus cases in 2 consecutive years (Figure 2). We assume that rotavirus diarrhea requiring hospital admission occur year round without any seasonal trend.

This study has several limitations, such as the stool specimen of the diarrhea cases were not cultured, so we did not know the characterization of the non-rotavirus diarrhea that may be consisting of both viral nonrotavirus and non-viral diarrhea. This study also did not include outpatient children; therefore we did not know the burden and risk factors for all rotavirus diarrhea in Denpasar.

\section{Conclusions}

The prevalence of diarrhea at Sanglah Hospital was 11.3\%. The prevalence of rotavirus diarrhea was $49.8 \%$. The results of this study confirmed that diarrhea remains an important cause of hospitalization in children, and rotavirus was the most important etiology of diarrhea. The peak prevalence was between 6 and 24 months of age. We also found that boys were more susceptible to rotavirus infection than girls. Rotavirus diarrhea in hospitalized children was manifested as fever and vomiting more often than one symptom alone. In these children, good nutritional status and breastfeeding provided the same protection against rotavirus and non-rotavirus diarrhea.

\section{Abbreviations}

IQR: Interquartile range; WHO: World Health Organization.

\section{Competing interests}

The authors declare that they have no competing interests.

\section{Authors' contributions}

All authors read and approved the final manuscript. HS participated in the design of the study, data collection, statistical analysis, and helped draft the manuscript. SB and YS participated in the design of the study, data collection, and helped draft the manuscript. IPGK participated in data collection and helped draft the manuscript. IGNSP participated in the design of the study and helped draft the manuscript.

\section{Authors' information}

$\mathrm{HS}$ is the Master of Biomedicine and pediatric researcher in the Department of Child Health, Medical School, Udayana University/Sanglah Hospital. IPGK and IGNSP are pediatric gastroenterology consultants and researchers in the Department of Child Health, Medical School, Udayana University/ Sanglah Hospital.

SB is the Professor of Child Growth and Development - Social Pediatrics in the Department of Child Health, Medical School, Udayana University/Sanglah Hospital.

YS is the Professor of Pediatric Gastroenterology in the Department of Child Health, Medical School, Gadjah Mada University/Sardjito Hospital. She is the project head of Extension for Hospital-based Surveillance and Strain

Characterization of Rotavirus Diarrhea Indonesia. 


\section{Acknowledgements}

We thank Sukanto, IP. (PT Bio Farma) for the laboratory work; and Abdu Wahab and Althaf Setyawan (Community Health and Nutrition Research Laboratory, Faculty of Medicine, Gadjah Mada University) for data analysis. We also thank doctors, nurses, administrative staff and research assistants in the Department of Child Health, Faculty of Medicine, Udayana University/ Sanglah Hospital for their help in this study.

\section{Funding source}

Salary and/or intellectual support was provided by WHO Regional Office for South East Asia (SEARO) to all authors during this study.

\section{Financial disclosure}

The authors have no financial relationships to disclose that are relevant to this article.

\section{Author details}

'Division of Gastroenterology and Hepatology, Department of Child Health, Medical School, Udayana University/Sanglah Hospital, Denpasar, Indonesia. ${ }^{2}$ Division of Child Growth and Development - Social Pediatrics, Department of Child Health, Medical School, Udayana University/Sanglah Hospital, Denpasar, Indonesia. ${ }^{3}$ Division of Gastroenterology and Hepatology, Department of Child Health, Medical School, Gadjah Mada University/Sardjito Hospital, Yogyakarta, Indonesia.

Received: 24 December 2013 Accepted: 19 March 2014

Published: 26 March 2014

\section{References}

1. Parashar UD, Gibson CJ, Bresee JS, Glass RI: Rotavirus and severe childhood diarrhea. Emerg Infect Dis 2006, 12:304-306.

2. Bahl R, Ray P, Subodh S, Shambharkar P, Saxena M, Parashar U, Gentsch J, Glass R, Bhan MK, Delhi Rotavirus Study Group: Incidence of severe rotavirus diarrhea in New Delhi, India, and G and P Types of the infecting rotavirus strains. J Infect Dis 2005, 192:S114-S119.

3. Junaid SA, Umeh C, Olabode AO, Banda JM: Incidence of rotavirus infection in children with gastroenteritis attending Jos university teaching hospital, Nigeria. Virol J 2011, 8:233.

4. Wobudeya E, Hanifa B, Karamagi CK, Kalyango JN, Mutebi E, Wamani H: Breastfeeding and the risk of rotavirus diarrhea in hospitalized infants in Uganda: a matched case control study. BMC Pediatr 2011, 11:1-7.

5. Parashar UD, Burton A, Lanata C, Boschi-Pinto C, Shibuya K, Steele D, Birmingham M, Glass Rl: Global mortality associated with rotavirus disease among children in 2004. J Infect Dis 2009, 200:S9-S15.

6. Wilopo SA, Soenarto Y, Bresee JS, Tholib A, Aminah S, Cahyono A, Gentsch JR, Kilgore P, Glass RI: Rotavirus surveillance to determine disease burden and epidemiology in Java, Indonesia, August 2001 through April 2004. Vaccine 2009, 27S:F61-F66.

7. World Health Organization: The Treatment of Diarrhea: A Manual for Physicians and other Senior Health Workers. Geneva: World Health Organization; 2005

8. Gaffey MF, Wazny K, Bassani DG, Bhutta ZA: Dietary management of childhood diarrhea in low- and middle-income countries: a systematic review. BMC Public Health 2013, 13(Suppl 3):S17.

9. Back RE: Persistent diarrhea in children of developing countries. Pediatr Infect Dis J 1993, 12:751-762

10. Strand TA, Sharma PR, Gjessing HK, Ulak M, Chandyo RK, Adhikari RK, Sommerfelt $\mathrm{H}$ : Risk factors for extended duration of acute diarrhea in young children. PLoS One 2012, 7(5):e36436

11. World Health Organization: Generic Protocols for (i) Hospital-Based Surveillance to Estimate the Burden of Rotavirus Gastroenteritis in Children and (ii) A Community-Based Survey on Utilization of Health Care Services for Gastroenteritis in Children. Field Test Version. Geneva: Vaccine and Biologicals, World Health Organization; 2002

12. Sherchan JB, Ohara H, Sherchand JB, Tandukar S, Sakurada S, Gurung B, Ansari S, Rijal BP, Pokhrel BM: Molecular evidence based hospital acquired rotavirus gastroenteritis in Nepal. Prime J Microbiol Res 2011, 1:16-21.

13. Borade A, Bais A, Bapat V, Dhongade R: Characteristics of rotavirus gastroenteritis in hospitalized children in Pune. Indian J Med Sci 2010, 64:210-218.
14. World Health Organization: Rotavirus surveillance worldwide-2009. Weekly Epidemiol Record 2011, 86:174-176.

15. Bass CW, Dorsey KN: Rotavirus and other agents of viral gastroenteritis. In Nelson Textbook of Pediatrics. 16th edition. Edited by Richard E, Behrman F. Philadelphia: Raven Press; 2004:67-110.

16. World Health Organization scientific working group-1: Rotavirus and other viral diarrheas. Bull World Health Organ 1980, 58:183-198.

17. Soenarto Y, Aman AT, Bakri A, Waluya H, Firmansyah A, Kadim M, Martiza I, Prasetyo D, Mulyani NS, Widowati T, Soetjiningsih, Karyana IP, Sukardi W, Bresee J, Widdowson MA: Burden of severe rotavirus diarrhea in Indonesia. J Infect Dis 2009, 200:S188-S194.

18. Yolken RH, Peterson JA, Vonderfecht SL, Fouts ET, Midthun K, Newburg DS: Human milk mucin inhibits rotavirus replication and prevents experimental gastroenteritis. J Clin Invest 1992, 90:1984-1991.

19. Naficy AB, Abu-Elyazeed R, Holmes JL, Rao MR, Savarino SJ, Kim Y, Wierzba TF, Peruski L, Lee YJ, Gentsch JR, Glass Rl, Clemens JD: Epidemiology of rotavirus diarrhea in Egyptian children and implications for disease control. Am J Epidemiol 1999, 150:770-777.

20. Duffy LC, Byers TE, Riepenhoff-Talty M, La-Scolea LJ, Zielezny M, Ogra PL: The effects of infant feeding on rotavirus-induced gastroenteritis: a prospective study. Am J Public Health 1986, 76:259-263.

doi:10.1186/1471-230X-14-54

Cite this article as: Salim et al:: Risk factors of rotavirus diarrhea in hospitalized children in Sanglah Hospital, Denpasar: a prospective cohort study. BMC Gastroenterology 2014 14:54.

\section{Submit your next manuscript to BioMed Central and take full advantage of:}

- Convenient online submission

- Thorough peer review

- No space constraints or color figure charges

- Immediate publication on acceptance

- Inclusion in PubMed, CAS, Scopus and Google Scholar

- Research which is freely available for redistribution

Submit your manuscript at www.biomedcentral.com/submit
C Biomed Central 